\title{
BREXIT AND THE IMPLICATIONS FOR TACIT CHOICE OF LAW IN THE UNITED KINGDOM
}

\author{
Garth Bouwers \\ LLB LLM \\ Lecturer, University of Johannesburg
}

\section{SUMMARY}

The influence of European Union law on the United Kingdom is noteworthy. In the commercial arena, it has transformed the rules of private international law in the United Kingdom. The European Union has established a common framework for jurisdiction of national courts, the recognition and enforcement of judgments and the determination of the applicable law. The article highlights the implications of Brexit on the determination of the applicable law in the United Kingdom, more specifically, its impact on a tacit choice of law in international commercial contracts. The article examines the current legal position in the United Kingdom (i.e. the legal framework in a so-called "soft-Brexit" scenario). Secondly, the article analyses the effect of a complete withdrawal from the European Union (i.e. the legal framework in a "hardBrexit" scenario).

\section{BREXIT: A BRIEF HISTORY}

Theresa May, Prime Minister of the United Kingdom (UK), declared with some assertiveness that "Brexit means Brexit", when speaking in the aftermath of the referendum on 23 June 2016, when the citizens of the UK narrowly voted $(51.9 \%$ to $48.1 \%)$ to leave the European Union (EU). ${ }^{1}$ With the shockwaves of the decision to leave the EU still reverberating around the world, those acquainted with British history should not at all be surprised with the outcome of the referendum. ${ }^{2}$

The sentiment of the British people has always been mixed or even hostile toward European integration. ${ }^{3}$ Lord Palmerston best portrays the long-held attitude of the British in a speech to the House of Commons in 1848:

Dickinson "Back to the Future: The UK's EU Exit and the Conflict of Laws" 201612 Journal of Private International Law 195; MacMillan "The Impact of Brexit upon English Contract Law" 201627 King's LJ 420; Király “Brexit in Context” 2016 Eötvös Loránd University LJ 39. Király 2016 Eötvös Loránd University LJ 47.

3 Martonyi "Brexit. Brexit?" 2016 Eötvös Loránd University LJ 19 22; Király 2016 Eötvös Loránd University LJ 39. 
"I hold with respect to alliances, that England is a power sufficiently strong, sufficiently powerful, to steer her own course, and not to tie herself as an unnecessary appendage to the policy of any government ... We have no eternal allies, and we have no perpetual enemies. Our interests are eternal and perpetual, and those interests it is our duty to follow ...

More recently, Winston Churchill, who, on the one hand supported the idea of a unified Europe, ${ }^{5}$ never thought that Britain should be a part of that unification. ${ }^{6}$ A highly regarded British citizen was asked days after the leave vote about his views on the outcome, to which he responded: "You know very well that I was for Brexit even before the UK joined the European Community."7 These feelings reflect a significant part of British society's attitude toward Europe, reservations shared by some on continental Europe.

In 1963 and 1967, French president Charles De Gaulle vetoed British accession to the European Communities. ${ }^{8}$ De Gaulle thought that the British would be different, as they always have been; that they will never be entirely committed in their heart and mind to the European integration project. ${ }^{9}$ The British had to wait until De Gaulle's resignation to become a member of the European Community. ${ }^{10}$ The negotiations on the terms of the accession were not easy, and despite dissenting opinions throughout the process, the European Communities Bill was finally passed by both Houses of Parliament and entered into force on 1 January $1973 .{ }^{11}$ It has taken the better part of fifty years for Charles De Gaulle's premonition to be realised. ${ }^{12}$

The outcome of the British referendum has landed a knockout blow to the already rocky relationship between the British and those across the English Channel. It solidifies the negative perception among the Member States regarding British attitudes towards Europe, while sending a clear message to the political elite in Britain. Martonyi describes this as follows:

4 Speech to the House of Commons on 1 March 1848 as referred to in Király 2016 Eötvös Loránd University LJ 39.

5 See, for eg, Király 2016 Eötvös Loránd University LJ 40. Winston Churchill wrote the following note: "I must admit that my thoughts rest primarily in Europe - the revival of the glory of Europe, the parent continent of the modern nations and civilisation ... I look forward to a United States of Europe in which the barriers between the nations will be greatly minimised and unrestricted travel will be possible. I hope to see the economy of Europe studied as a whole."

6 Martonyi 2016 Eötvös Loránd University LJ 22; Király 2016 Eötvös Loránd University LJ 40-41.

Martonyi 2016 Eötvös Loránd University LJ 22.

8 Király 2016 Eötvös Loránd University LJ 45.

9 Martonyi 2016 Eötvös Loránd University LJ 22. See, also, Király 2016 Eötvös Loránd University LJ 45: "During the sixties the position of the European Community was dominated by the French president De Gaulle, who was more than sceptical about the UK's membership, considering the country the US 'Trojan Horse' in Europe ..."

10 Király 2016 Eötvös Loránd University LJ 45.

11 See, generally, Király 2016 Eötvös Loránd University LJ 45-47. The European Communities Act 1972 made provision for the enlargement of the European Communities to include the United Kingdom, together with (for certain purposes) the Channel Islands, the Isle of Man and Gibraltar.

12 Martonyi 2016 Eötvös Loránd University LJ 27; Király 2016 Eötvös Loránd University LJ 47. 
"The general sentiment of loss of control over economic and political decisions, the growing mistrust in institutions, the widening distance between decision making and 'ordinary citizens' and all the frustrations and antiestablishment anger resulting therefrom did make an important contribution to the final outcome ..."

So, when Mrs May declared that "Brexit means Brexit", was she really left with any other option?

\section{CONSEQUENCES OF BREXIT}

It is almost certain that the UK's membership of the EU will cease to exist. The British government has triggered article 50 of the Treaty on [the] European Union, which allows member states to withdraw from the EU. ${ }^{14}$ The negotiations between the UK and her EU partner as to the terms of the withdrawal have commenced, and there can be no doubt that it will be as tedious as accession negotiations. ${ }^{15}$ These are the only points of certainty on what Brexit entails. Without the ability to see into the future, the terms of the negotiations cannot be predicted. ${ }^{16}$

The impact that Brexit will have, depends largely on the mode of exit, and the model of interaction established between the parties thereafter. ${ }^{17}$ The final meaning of Brexit will lie on a scale with something less than full membership at one end, and total exclusion of the UK from the EU at the other end. ${ }^{18}$ This uncertainty has not only thrown up political complications, but also numerous legal problems concerning the disengagement of the UK from the EU. ${ }^{19}$ One such problem concerns the UK's continuing relationship under Title $\mathrm{V}$ of the Treaty on the Functioning of the European Union, more

13 Martonyi 2016 Eötvös Loránd University LJ 21.

14 The two principle treaties on which the EU is based are the Treaty on European Union (TEU) and the Treaty on the Functioning of the European Union (TFEU). Article 50 of the TEU provides that any Member State may decide to withdraw from the European Union in accordance with its own constitutional requirements. A Member State, which decides to withdraw, shall notify the European Council of its intention. The EU shall negotiate and conclude an agreement with that State, setting out the arrangements for its withdrawal, taking account of the framework for its future relationship with the Union. That agreement shall be negotiated in accordance with Article 218(3) of the Treaty on the Functioning of the European Union. The treaties shall cease to apply to the State in question from the date of entry into force of the withdrawal agreement or, failing that, two years after the notification, unless the European Council, in agreement with the Member State concerned, unanimously decides to extend this period. See, also, Maican "Legal Aspects of Brexit" 20166 Juridical Tribune 252

15 Dickinson 201612 Journal of Private International Law 195. See, generally, Király 2016 Eötvös Loránd University LJ 45-47.

16 Dickinson 201612 Journal of Private International Law 197.

17 Schillig "Corporate Law after Brexit" 201627 King's LJ 431.

18 MacMillan 201627 King's LJ 420.

19 Fitchen "Brexit and EU Private International Law: Cross-border Judgements - Unintended Consequences" (7 July 2007) https://aberdeenunilaw.wordpress.com/2016/07/07/brexitand-eu-private-international-law-cross-border-judgments-unintended-consequences/ (accessed 2017-06-20) 
specifically, under Chapter 3 (judicial cooperation in civil matters).$^{20}$ It seems unlikely that many voters, when deciding to vote in favour of Brexit, would have given any thought to the profound consequences of their decision on the UK's civil justice system. ${ }^{21}$ The impact that EU law has had on the UK is worth mentioning. More precisely, in the commercial arena, "it has revolutionized the rules applicable to dispute resolution in a cross-border context, i.e. those that we would identify as rules of private international law". ${ }^{22}$ The EU has established a common framework for jurisdiction of national courts, the determination of the applicable law and the recognition and enforcement of judgments. ${ }^{23}$ Briggs describes the immense influence that European law has on the subject of private international law in the UK:

"[W]e have had a wholly new version of our subject laid down and still being laid out ... It is no longer English law. Its civil and commercial core, in particular, has been taken over and is now European laws written in a mixture of black letters and invisible ink. Though the common law still controls some important parts of the subject, this territory is gradually being lost, and the

20 Dickinson 201612 Journal of Private International Law 195. See art 67 the Treaty on the Functioning of the European Union: "(1) The Union shall constitute an area of freedom, security and justice with respect for fundamental rights and the different legal systems and traditions of the Member States." "(4) The Union shall facilitate access to justice, in particular through the principle of mutual recognition of judicial and extrajudicial decisions in civil matters." Article 81 provides: "(1) The Union shall develop judicial cooperation in civil matters having cross-border implications, based on the principle of mutual recognition of judgments and of decisions in extrajudicial cases. Such cooperation may include the adoption of measures for the approximation of the laws and regulations of the Member States. (2) For the purposes of paragraph 1, the European Parliament and the Council, acting in accordance with the ordinary legislative procedure, shall adopt measures, particularly when necessary for the proper functioning of the internal market, aimed at ensuring: (a) the mutual recognition and enforcement between Member States of judgments and of decisions in extrajudicial cases; (b) the cross-border service of judicial and extrajudicial documents; (c) the compatibility of the rules applicable in the Member States concerning conflict of laws and of jurisdiction; (d) cooperation in the taking of evidence; (e) effective access to justice; (f) the elimination of obstacles to the proper functioning of civil proceedings, if necessary by promoting the compatibility of the rules on civil procedure applicable in the Member States."

21 Dickinson 201612 Journal of Private International Law 196; Hill "Brexit and Private International Law" (6 July 2017) http://legalresearch.blogs.bris.ac.uk/2016/07/brexit-and-private-international-law/ (accessed 2017-06-20); Fitchen https://aberdeenunilaw.wordpress. com/2016/07/07/brexit-and-eu-private-international-law-cross-border-judgments-unintended -consequences/; Requejo "Brexit and Private International Law, Over and Over" (27 March 2017) http://lawofnationsblog.com/2017/03/27/brexit-private-international-law/ (accessed 2017-06-18).

22 Dickinson 201612 Journal of Private International Law 196; Hill http://legalresearch.blogs.bris.ac.uk/2016/07/brexit-and-private-international-law/; and Requejo http://lawofnationsblog.com/2017/03/27/brexit-private-international-law/.

23 Dickinson 201612 Journal of Private International Law 196; Rühl "The Effect of Brexit on the Resolution of International Disputes - Choice of Law and Jurisdiction in Civil and Commercial Matters" (13 April 2017) www.law.ox.ac.uk/business-law-blog/blog/2017/04/ brexit-negotiations-series-effect-brexit-resolution-international (accessed 2017-06-19); Hill http://legalresearch.blogs.bris.ac.uk/2016/07/brexit-and-private-international-law/. See, also, Fitchen https://aberdeenunilaw.wordpress.com/2016/07/07/brexit-and-eu-private-international-law-cross-border-judgments-unintended-consequences/: "The EU has put in place many PIL Regulations to replace the different complex national answers to these basic questions with harmonized answers (in different Regulations) applying across all (or nearly all) EU Member States." 
common law rules of private international law are losing the universality which gave them their coherence. All this means that it no longer makes sense to think of our private international law as English. Its waters flow into two streams, but while one is in spate, the other is looking rather parched."

Given the dependency in the UK on European private international law Regulations, the question of how Brexit will affect the legal framework for the resolution of international disputes becomes imperative.

This paper will explore the possible ramifications of Brexit on private international law in the UK, more specifically, its impact for tacit choice of law in international commercial contracts. ${ }^{26}$ The current legal position in the UK (i.e. the legal framework in a so-called "soft-Brexit" scenario) will be examined. $^{27}$ Secondly, an analysis of the complete withdrawal from the EU (i.e. the legal framework in a "hard-Brexit" scenario) will be conducted. ${ }^{28}$

24 Briggs Private International Law in English Courts (2014) preface.

25 Rühl www.law.ox.ac.uk/business-law-blog/blog/2017/04/brexit-negotiations-series-effectbrexit-resolution-international; Fitchen https://aberdeenunilaw.wordpress.com/2016/07/07/ brexit-and-eu-private-international-law-cross-border-judgments-unintended-consequences/.

26 Rühl www.law.ox.ac.uk/business-law-blog/blog/2017/04/brexit-negotiations-series-effectbrexit-resolution-international. See the Draft Agreement on the Withdrawal of the United Kingdom of Great Britain and Northern Ireland from the European Union and the European Atomic Energy Community per https://ec.europa.eu/commission/sites/beta-political/files/draft agreement coloured.pdf (3/4/2018). The EU and the UK have reached an agreement on the transition period for Brexit. The transition period will commence from 29 March 2019 until 31 December 2020. During the transition period, the parties have agreed, subject to technical legal revision, to the application by the UK of the Rome I Regulation. See article 62 of the Draft Agreement in this regard.

27 Rühl www.law.ox.ac.uk/business-law-blog/blog/2017/04/brexit-negotiations-series-effectbrexit-resolution-international; MacMillan 201627 King's LJ 421; and Dickinson 201612 Journal of Private International Law 197. For the purpose of the current discussion, a softBrexit scenario will maintain the current legal framework in the UK i.e. the application of the Rome I Regulation (or something similar i.e. the Rome Convention) for the settlement of private international law disputes, more specifically, those relating to the choice of the applicable law. For the meaning of what a soft Brexit may entail in the political discourse see, generally, Kende and Katona "In the Crystal Ball: Outside the EU and What the UK Will Find There" 2016 Eötvös Loránd University LJ 73; Sims "What is the Difference between Hard and Soft Brexit? Everything you Need to Know" (3 October 2016) https://www.independent.co.uk/news/uk/politics/brexit-hard-soft-what-is-the-difference-ukeu-single-market-freedom-movement-theresa-may-a7342591.html (accessed 2018-04-03); and John "What Exactly is a 'Hard Brexit', Anyway?" (17 January 2017) http://time.com/4635762/theresa-may-hard-brexit-britain / (accessed 2018-04-03).

28 Rühl www.law.ox.ac.uk/business-law-blog/blog/2017/04/brexit-negotiations-series-effectbrexit-resolution-international; MacMillan 201627 King's LJ 421; Fitchen https://aberdeenunilaw.wordpress.com/2016/07/07/brexit-and-eu-private-international-lawcross-border-judgments-unintended-consequences/; Dickinson 201612 Journal of Private International Law 197; and Schillig 201627 King's LJ 431. For the purpose of the current discussion, a hard Brexit would represent a complete withdrawal from EU private international instruments currently in force in the UK. In a hard-Brexit scenario, the UK would have to resort to the traditional common-law position for the settlement of private international law disputes, more specifically, those relating to the choice of the applicable law. For the meaning of what a hard Brexit may entail in the political discourse, see, generally, Kende and Katona 2016 Eötvös Loránd University LJ 73; Sims https://www.independent. co.uk/news/uk/politics/brexit-hard-soft-what-is-the-difference-ukeu-single-market-freedom-movement-theresa-may-a7342591.html; and John http://time.com/4635762/-theresa-may-hard-brexit-britain. 


\section{A SOFT BREXIT}

\section{Introduction}

There is no straightforward solution concerning the many important areas of private international law in the UK that are currently contained in EU Regulations that will cease to apply immediately after Brexit, unless legislators take action. ${ }^{29}$ Following the formal Brexit negotiations, the assumption is that the application of the EU Treaties will end in the UK, and the European Communities Act 1972 will be repealed. ${ }^{30}$ The latter step will have the effect that all key EU private international instruments, including inter alia ${ }^{31}$ the Rome I Regulation (which deals with the determination of the applicable law for contractual obligations) ${ }^{32}$ will be stripped of its legal force. ${ }^{33}$ However, the repeal of the European Communities Act 1972 and the inevitable abolishment of key EU private international law instruments would not necessarily return private international law in the UK to a pre-1972 state (i.e. before accession to the European Economic Communities). ${ }^{34}$

29 Fitchen https://aberdeenunilaw.wordpress.com/2016/07/07/brexit-and-eu-private-international-law-cross-border-judgments-unintended-consequences/.

30 Dickinson 201612 Journal of Private International Law 197.

31 See Dickinson 201612 Journal of Private International Law 197-198. Most notably, the Brussels I (bis) Regulation (EC) No 1215/2012 of the European Parliament and of the Council on jurisdiction and the recognition and enforcement of judgments in civil and commercial matters (recast) ([2012] OJ L351/1) (2012 Brussels I Regulation); Brussels II (bis) Regulation (EC) No $2201 / 2003$ concerning jurisdiction and the recognition and enforcement of judgments in matrimonial matters and the matters of parental responsibility, repealing Regulation (EC) No 1347/2000 ([2003] OJ L338/1); Rome II Regulation (EC) No $864 / 2007$ of the European Parliament and of the Council on the law applicable to noncontractual obligations (Rome II) ([2007] OJ L199/40); The Maintenance Regulation (EC) No 4/2009 on jurisdiction, applicable law, recognition and enforcement of decisions and cooperation in matters relating to maintenance obligations ([2009] OJ L7/1), as applied to the UK by Commission Decision 2009/451/EC ([2009] OJ L149/73); Evidence Regulation (EC) No 1206/2001 of 28 May 2001 on cooperation between the courts of the Member States in the taking of evidence in civil or commercial matters ([2001] OJ L174/1); Service Regulation (EC) No 1393/2007 of the European Parliament and of the Council of 13 November 2007 on the service in the Member States of judicial and extrajudicial documents in civil or commercial matters (service of documents ([2007] OJ L324/79); Insolvency Regulation (EC) No $1346 / 2000$ on insolvency proceedings ([2000] OJ L160/1, to be replaced by Regulation (EU) No 2015/848 of 20 May 2015 on insolvency proceedings (recast) [2015] OJ L141/19). See, also, Dickinson 201612 Journal of Private International Law 198: "The same would be true of international agreements concluded by the EU ... which (as the matter stand) bind the UK only indirectly through its EU treaty obligations." These agreements include the 2007 Lugano Convention on jurisdiction and the recognition and enforcement of judgments in civil and commercial matters (Lugano, 31 October 2007) ([2007] OJ L339/3) and the Hague Convention on choice of court agreements (30 June 2005).

32 Regulation (EC) No 593/2008 of the European Parliament and of the Council on the Law Applicable to Contractual Obligations (Rome I) ([2008] OJ L177/6), as applied to the UK by Commission Decision 2009/26/EC ([2009] OJ L10/22). See, also, Hill http://legalresearch. blogs.bris.ac.uk/2016/07/brexit-and-private-international-law/.

Dickinson 201612 Journal of Private International Law 197.

34 Dickinson 201612 Journal of Private International Law 198. 
Before legislative capability was transferred to the EU, the UK's membership to the European Economic Community led to its involvement in numerous conventions in the area of private international law, ${ }^{35}$ a notable inclusion being the 1980 Rome Convention, ${ }^{36}$ which preceded the Rome I Regulation. ${ }^{37}$ Reflecting its separateness from the EU treaties, the Rome Convention was given force of law in the UK by the Contracts (Applicable Law) Act $1990,{ }^{38}$ and not through the European Communities Act 1972. ${ }^{39}$ Despite the fact that the Rome I Regulation has superseded the Rome Convention, ${ }^{40}$ questions arise as to whether the Convention will revive on the repeal of the 1972 Act. $^{41}$ Dickinson provides the following argument in this regard:

"As to the UK's withdrawal from the EU, the 1980 Rome Convention was open for signature by parties who (at that time) were members of the EEC. The UK met that condition. Although not perpetual, the Convention remains in force as it applies to relations with Denmark and to overseas territories to which the EU treaties do not extend (eg, Faeroe Islands, Greenland, Aruba, Netherlands Antilles). Finally, although Art 24 of the Rome I Regulation provided that the Regulation shall replace the Rome Convention in the Member States, the UK would no longer be a Member State and the wording of Art 24 strongly supports the contention that the Convention was intended to remain applicable in territories to which the Regulation does not apply pursuant to the TFEU. If the UK (and all other parties to the Rome Convention - 27 of the 28 current Member States) would remain under an international obligation vis-àvis Denmark and Member States who have chosen to extend the Convention to non-EU territories, it seems strongly arguable that, upon withdrawal, the UK's treaty obligations (as well as its entitlements) should revive as regards to all Member States."

In the event that the Rome I Regulation ceases to apply in the UK, there appears no impediment to UK courts reverting to the (largely identical) Rome

Dickinson 201612 Journal of Private International Law 199; Hill http://legalresearch.blogs. bris.ac.uk/2016/07/brexit-and-private-international-law/.

36 Convention on the Law Applicable to Contractual Obligations (1980). See, generally, Mandery Party Autonomy in Contractual and Non-Contractual Obligations (2014) 27: "It established uniform rules of choice of law in contract in order to advance the unification of and eliminate the inconveniences arising from the diversity of the rules of conflict within the European Community." See, also, Dickinson 201612 Journal of Private International Law 199: other examples include the Brussels Convention on Jurisdiction and the Enforcement of Judgments in Civil and Commercial Matters (1968) and the Lugano Convention on the Law Applicable to Contractual Obligations (1988).

37 Dickinson 201612 Journal of Private International Law 199; Hill http://legalresearch.blogs. bris.ac.uk/2016/07/brexit-and-private-international-law/.

38 S 2(1) of the 1990 Act provides that the Rome Convention "shall have the force of law in the United Kingdom".

39 Dickinson 201612 Journal of Private International Law 199; Hill http://legalresearch.blogs. bris.ac.uk/2016/07/brexit-and-private-international-law/.

40 Article 24: "This Regulation shall replace the Rome Convention in the Member States, except as regards the territories of the Member States which fall within the territorial scope of that Convention and to which this Regulation does not apply pursuant to Article 299 of the Treaty." See, generally, Mandery Party Autonomy in Contractual and Non-Contractual Obligations 28-29.

41 Dickinson 201612 Journal of Private International Law 201.

42 Dickinson 201612 Journal of Private International Law 203-204. 
Convention through the Contracts (Applicable law) Act $1990 .^{43}$ This option would contribute to circumventing the legal uncertainty for choice of law rules in the UK post-Brexit.

Alternatively, the UK legislators may attempt to negotiate with the EU in order to minimise the cross-border risks for their citizens. ${ }^{44}$ If private international law considerations are placed high enough on the agenda at the negotiating table, it may lead to the UK being able to retain the benefits of some of the existing EU Regulations. ${ }^{45}$ It can be argued that judicial cooperation was never high on the agenda for the "Brexiteers" in any event, therefore preserving the status quo regarding EU private international law Regulations would probably not do much harm politically. ${ }^{46}$

The proposed introduction of the "Great Repeal Bill" may be indicative of the UK's intention in regards to some sort of retention of EU law. ${ }^{47}$ Prime Minister Theresa May has announced that the Government intends to introduce the Great Repeal Bill, which will come into force when the UK leaves the EU. ${ }^{48}$ The Bill would repeal the European Communities Act 1972 and simultaneously convert all EU legislation in force in the UK into British law. ${ }^{49}$ This would avert the significant degree of legal uncertainty that would immediately follow the repeal of the 1972 Act. $^{50}$

\section{Party autonomy and tacit choice of law}

As outlined above, in a soft-Brexit scenario, the Rome I Regulation (or the Rome Convention) will continue to apply in the UK post-Brexit. The Regulation constitutes a set of uniform conflict rules, replacing the private international law of contract of member states in respect of certain types of contractual obligations. ${ }^{51}$ Subject to certain limitations, ${ }^{52}$ the Regulation

43 Dickinson 201612 Journal of Private International Law 202 and 210; Hill http://legal research.blogs.bris.ac.uk/2016/07/brexit-and-private-international-law/. See, Mandery Party Autonomy in Contractual and Non-Contractual Obligations 30: "Much of the wording of the Convention has been simply adopted in Rome I with only minor modifications. In particular, Article 3 and the freedom of choice of the applicable law by the parties, is reaffirmed in Rome I with only minor amendments."

44 Fitchen https://aberdeenunilaw.wordpress.com/2016/07/07/brexit-and-eu-private-international-law-cross-border-judgments-unintended-consequences/.

45 Ibid.

46 Rühl www.law.ox.ac.uk/business-law-blog/blog/2017/04/brexit-negotiations-series-effectbrexit-resolution-international.

47 Rühl www.law.ox.ac.uk/business-law-blog/blog/2017/04/brexit-negotiations-series-effectbrexit-resolution-international; MacMillan 201627 King's LJ 424; Maican 20166 Juridical Tribune 254.

48 MacMillan 201627 King's LJ 424; Maican 20166 Juridical Tribune 254.

49 Ibid.

50 MacMillan 201627 King's LJ 424.

51 Par $32-35$ is based on Bouwers "Tacit Choice of Law in International Commercial Contracts - the Position in South Africa and Under the Rome I Regulation" 201786 Transnational Impacts on Law - Perspectives from South Africa and Germany 69. See Article 1 of the Rome I Regulation. Member States of the European Union refer to Austria, Belgium, Bulgaria, Croatia, Cyprus, the Czech Republic, Denmark, Estonia, Finland, France, Germany, Greece, Hungry, Ireland, Italy, Latvia, Lithuania, Luxembourg, Malta, the Netherlands, Poland, Portugal, Romania, Slovakia, Slovenia, Spain, Sweden, and the 
recognises the principle of party autonomy. ${ }^{53}$ Recital 11 of the Rome I Regulation provides that "[t]he parties' freedom to choose the applicable law should be one of the cornerstones of the system of conflict-of-law rules in matters of contractual obligations". The principle of party autonomy is enunciated in article 3(1) of the Regulation (the basic provision on choice of law): "A contract shall be governed by the law chosen by the parties. The choice shall be made expressly or clearly demonstrated by the terms of the contract or the circumstances of the case ..." Parties may exercise their choice by stating expressly the law applicable to their contract, or the court can find that they had tacitly agreed on the applicable law. Although falling short of an express choice by the parties, a tacit choice still amounts to a true or real choice of law. ${ }^{54}$

\section{Level of strictness for a tacit choice of law}

To give effect to the real or true intention of the parties, "the criteria for identifying a tacit [or implied] choice of law must be articulated clearly and stringently". 55 The level of strictness of the criterion under the Rome I

United Kingdom. Denmark is the only country that continues to apply the Rome Convention. The reach that the Rome I Regulation, together with its predecessor, the Rome Convention has had, is noteworthy. See, for eg, Neels Rome in the Far East unpublished lecture at the University of Amsterdam, the University of British Columbia and the University of Johannesburg (2011-2012) 1: the basic provisions of codifications in many states are in principle based on the Rome model, including non-EU European countries such as Liechtenstein, Macedonia, Russia, Switzerland and the Ukraine; countries in the Far East, including China, Japan, Mongolia and South Korea; as well as countries in the Middle East such as Azerbaijan, Turkey and Uzbekistan.

52 See, for eg, art 9 (overriding mandatory provisions) and art 21 (public policy of the forum) of the Rome I Regulation. See, in general, Symeonides "Party Autonomy in Rome I and II: An Outsider's Perspective" 2010 Nederlands Internationaal Privaatrecht 191 194-200. A discussion on the limitations is beyond the scope of this article.

53 See, for eg, Bogdan Private International Law in Sweden (2016) 66; Bonomi "Rome I Regulation on the Law Applicable to Contractual Obligations - Some General Remarks" 200810 Yearbook of Private International Law 165 169; Collins (gen ed) Dicey, Morris and Collins on the Conflict of Laws II (2012) 1798; Mandery Party Autonomy in Contractual and Non-Contractual Obligations 31-32; Schwenzer, Hachem and Kee Global Sales and Contract Law (2012) 53; and Symeonides 2010 Nederlands Internationaal Privaatrecht 194.

54 Collins (gen ed) Dicey, Morris and Collins on the Conflict of Laws II 1809; Forsyth Private International Law. The Modern Roman-Dutch Law including the Jurisdiction of the High Courts (2012) 326-327; Mandery Party Autonomy in Contractual and Non-Contractual Obligations 47; Marshall "Reconsidering the Proper Law of the Contract" 201213 Melbourne Journal of International Law 501 512-513; Neels and Fredericks "Tacit Choice of Law in the Hague Principles on Choice of Law in International Contracts" 2011 De Jure 101 104; and Nygh Autonomy in International Contracts (1999) 108-109. See, also, Bogdan Private International Law in Sweden 66: "[T]he choice must be a real choice, so that a hypothetical reasoning about which law the parties would probably have chosen if they had made a choice is not sufficient." See the Hague Conference on Private International Law Principles of Choice of Law in International Commercial Contracts (2015) (Official Commentary) par 46.

55 Nygh Autonomy in International Contracts 111; and Marshall 2012 Melbourne Journal of International Law 516. See, also, Mandery Party Autonomy in Contractual and NonContractual Obligations 47: "Although Article 3(1) allows for an implied choice of law agreement, a court may not impute a choice of law on the basis that had the parties chosen 
Regulation requires the tacit choice to be "clearly demonstrated" ${ }^{56}$ while the formulation under the predecessor of the Rome I Regulation, the Rome Convention on the Law Applicable to Contractual Obligations, ${ }^{57}$ required that the tacit choice of law be "demonstrated with reasonable certainty". ${ }^{58}$ Neels and Fredericks argue that the formulation under the Rome Convention did not necessarily go far enough in the pursuance of legal determinability. ${ }^{59}$ To allow readily deduced tacit agreements may leave too much to the discretion of the individual judge, and, accordingly, could result in unpredictability of decision. ${ }^{60}$ The test under the Rome I Regulation requiring a tacit choice to be "clearly demonstrated" ensures a far greater measure of legal certainty and predictability of decision. ${ }^{61}$

a law, it would be the law of a particular country. Rather, it requires the courts to ascertain the true tacit will of the parties rather than a purely hypothetical will."

56 Article 3(1): "A contract shall be governed by the law chosen by the parties. The choice shall be made expressly or clearly demonstrated by the terms of the contract or the circumstances of the case ..."

57 Rome I Regulation. The Convention continues to apply to contracts concluded before 17 December 2009.

58 Article 3(1): "A contract shall be governed by the law chosen by the parties. The choice must be expressed or demonstrated with reasonable certainty by the terms of the contract or the circumstances of the case ..."

59 Neels and Fredericks "Revision of the Rome Convention on the Law Applicable to Contractual Obligations (1980): Perspectives from International Commercial and Financial Law" 2004 Revue européene de droit bancaire et financier / European Banking and Financial LJ (EUREDIA) 173 179, reprinted in 2006 Tydskrif vir die Suid-Afrikaanse Reg 121 125. See, also, Mandery Party Autonomy in Contractual and Non-Contractual Obligations 48.

60 Neels and Fredericks 2011 De Jure 106; Neels and Fredericks 2006 Tydskrif vir die SuidAfrikaanse Reg 125. See, also, Marshall 2012 Melbourne Journal of International Law 517. See the Official Commentary par 4 8-4 14.

61 See, for eg, Marshall 2012 Melbourne Journal of International Law 518 n 87: "The revision from the 'reasonable certainty' test under the Rome Convention to the 'clearly demonstrated' test under the Rome I Regulation was an attempt by the European Commission to quash the practice of the English and German courts in readily discerning a tacit choice where their French counterparts would not ... The French language version of the test, which requires that the choice of law result 'de façon certaine des dispositions du contrat ou des circonstances de la cause', remained unchanged in the transition from the Rome Convention to the Rome I Regulation." See, also, Mandery Party Autonomy in Contractual and Non-Contractual Obligations 48-49: "By substituting the words reasonable certainty with the words clearly demonstrated in Rome I, the uncertainty surrounding the word reasonable is removed. It may also be viewed as a stricter approach than taken under the Rome Convention. It indicates a preference for certainty over flexibility; the words clearly demonstrated leaving less room for discretionary interpretation by the courts." For a different view, see Plender and Wilderspin The European Private International Law of Obligations (2015) 148: "At first sight, this change of wording might be thought to require stronger evidence of the parties' intention than was the case under the Rome Convention. However, it is thought that that was not the intention of the legislature ... [T]here was a discrepancy between the French and English texts of the Convention ... The most likely explanation is that the change of wording in both language versions is simply prompted by a wish to align the different language versions while leaving the substantive meaning unchanged." 


\section{Indicators of a tacit choice}

The Rome I Regulation allows a tacit choice to be inferred by "the terms of the contract" or "the circumstances of the case". ${ }^{2}$ This means that a court, in deciding whether the parties have made a tacit choice of law, is not confined to the written agreement, but may take account of considerations surrounding the contract. ${ }^{63}$

The Giuliano and Lagarde Report, ${ }^{64}$ which accompanied the Rome Convention, lists some of the factors from which a tacit choice of law may be inferred. ${ }^{65}$ Some notable examples include the use of a standard form which is known to be drafted with reference to a particular system of law, ${ }^{66}$ the scenario where there has been an express choice of law in related transactions between the parties, ${ }^{67}$ and the inclusion of specific provisions of a particular legal system in the contract. ${ }^{68}$

After providing a list of examples from which a tacit choice of law may be inferred, the Giuliano and Lagarde Report states that article 3 of the Rome Convention does not permit a court to infer a choice of law where there is no clear indication of such choice. ${ }^{69}$ Although the report was written as a guide

62 Article 3(1). The wording used in the Rome Convention is identical in this regard.

63 Bogdan Private International Law in Sweden 66; Collins (gen ed) Dicey, Morris and Collins on the Conflict of Laws II 1809; Mandery Party Autonomy in Contractual and NonContractual Obligations 48; Marshall 2012 Melbourne Journal of International Law 518; McClean and Beevers The Conflict of Laws (2009) 360; Neels and Fredericks 2011 De Jure 106-107; Plender and Wilderspin The European Private International Law of Obligations 148; and Schwenzer et al Global Sales and Contract Law 55.

64 Giuliano and Lagarde "Report on the Convention on the Law Applicable to Contractual Obligations by Mario Giuliano and Paul Lagarde" 1980 Official Journal of the European Communities (OJ) C-282/01 15-17 (hereinafter "Giuliano and Lagarde Report") 17.

65 Giuliano and Lagarde 1980 Official Journal of the European Communities 17. See, also, Mandery Party Autonomy in Contractual and Non-Contractual Obligations 57: the examples provided by the Report are not exhaustive, but provide the most common situations from which a choice may be inferred.

66 Giuliano and Lagarde 1980 Official Journal of the European Communities 17. See, for eg, Collins (gen ed) Dicey, Morris and Collins on the Conflict of Laws II 1810; Nygh Autonomy in International Contracts 115; Mandery Party Autonomy in Contractual and NonContractual Obligations 55-56; and Plender and Wilderspin The European Private International Law of Obligations 154. See, also, Briggs Private International Law in English Courts 540: "[T]he retort that if the parties had chosen a law they would have said so may be rebutted by the equally simplistic observation that it is possible for parties to make a choice which they do not write into a contract which is presented as a standard form."

67 Giuliano and Lagarde 1980 Official Journal of the European Communities 17: "[A] previous course of dealing between the parties under contracts containing an express choice of law may leave the court in no doubt that the contract in question is to be governed by the law previously chosen where the choice of law clause has been omitted in circumstances which do not indicate a deliberate change of policy by the parties." See Collins (gen ed) Dicey, Morris and Collins on the Conflict of Laws II 1810; Mandery Party Autonomy in Contractual and Non-Contractual Obligations 57-58; Nygh Autonomy in International Contracts 116; and Plender and Wilderspin The European Private International Law of Obligations 156.

68 Giuliano and Lagarde 1980 Official Journal of the European Communities 17. See, also, Collins (gen ed) Dicey, Morris and Collins on the Conflict of Laws II 1813-1814; and Mandery Party Autonomy in Contractual and Non-Contractual Obligations 56-57.

69 Giuliano and Lagarde 1980 Official Journal of the European Communities 17. 
to the Rome Convention, nothing suggests that the position would have changed under the Rome I Regulation. The existence of any of the abovementioned factors as such should therefore not automatically be conclusive. They are mere indicators that a court must consider to determine whether it is clear that the parties intended to make a choice of law. ${ }^{70}$ This is particularly relevant when issues arise whether a choice of forum constitutes a choice of law.

\section{Choice of forum and tacit choice of law}

The legal systems of the world provide highly conflicting views in respect of the relationship between choice of forum and tacit choice of law by the parties. ${ }^{71}$ This diversity extends to the member states of the Rome I Regulation. ${ }^{72}$ Notably, the English and German courts have been liberal in inferring a choice of law from the presence of a jurisdiction or localised arbitration clause, while French courts were reluctant to draw this conclusion. $^{73}$

The Giuliano and Lagarde Report addressed this issue by proving that "[t]he choice of a particular forum may show in no uncertain manner that the parties intend the contract to be governed by the law of that forum, but this must always be subject to the other terms of the contract and all the circumstances of the case" ${ }^{74}$ However, Lagarde has since indicated that a jurisdiction clause is merely a factor to be considered, and may not, without more, be interpreted as establishing the unexpressed will of the parties. ${ }^{75}$

70 Collins (gen ed) Dicey, Morris and Collins on the Conflict of Laws II 1809. See, for eg, Mandery Party Autonomy in Contractual and Non-Contractual Obligations 56: "But the use of a standard form cannot by itself be taken as solely indicative of an intention of the parties. Thus, in the Egon Oldendorff case the existence of an English language form of charter party containing standard clauses based on well-known meanings of English law and the English arbitration clause were considered together as indicative of the parties' intention to have English law as the applicable law."

71 For an overview and references, see Neels "Choice of forum and Tacit Choice of Law: The Supreme Court of India and the Hague Principles on Choice of Law in International Commercial Contracts (An Appeal for an Inclusive Comparative Approach to Private International Law)" in International Institute for the Unification of Private Law (UNIDROIT) (ed) Eppur si muove - The Age of Uniform Law. Essays in honour of Michael Joachim Bonell to celebrate his $70^{\text {th }}$ birthday 20161358.

72 Marshall 2012 Melbourne Journal of International Law 519 n 95; Neels 2016 UNIDROIT 362-363; and Plender and Wilderspin The European Private International Law of Obligations 152-153. See, also, Mandery Party Autonomy in Contractual and NonContractual Obligations 49: a debate concerning jurisdiction and arbitration clauses is due to the different approaches taken in Member States to such agreements. Some regard their inclusion in a contract as clearly implying a choice of law, while others do not.

73 Plender and Wilderspin The European Private International Law of Obligations 152-153. See, also, Marshall 2012 Melbourne Journal of International Law 519 n 95: "Under the auspices of the Giuliano-Lagarde Report ... English courts continued to conform to the common law belief that a forum clause was a 'weighty indicator' when ascertaining tacit choice pursuant to the Rome Convention. While the German courts followed a similar trajectory, other contracting states, notably France, were loath to draw the inference." Giuliano and Lagarde 1980 Official Journal of the European Communities 17

75 See Lagarde "Le nouveau droit international privé des contrats" 80 (1991) Revue critique de droit international privé (Rev crit dip) 287303 as referred to in Nygh Autonomy in 
The European Group of Private International Law (GEDIP) ${ }^{76}$ is also of the opinion that the choice of a court of a given state shall not in itself be equivalent to a choice of the law of that state.

While article 3 of the Rome I Regulation is silent on the matter, ${ }^{78}$ recital 12 attempts to clarify the issue by stating:

"An agreement between the parties to confer on one or more courts or tribunals of a Member State exclusive jurisdiction to determine disputes under the contract should be one of the factors to be taken into account in determining whether a choice of law has been clearly demonstrated."

However, it does not appear that recital 12 provides much clarity. On the one hand, it may be read as support for the idea that a choice of forum is not sufficient to indicate a choice of law but may be a factor to be taken into account, ${ }^{79}$ and, on the other, that a choice of forum may on its own indicate a choice of law. ${ }^{80}$ The divergent practices of the member states of the Rome I Regulation will undoubtedly continue as long as the fora in these states are free to determine how much weight is to be attached to a choice of forum clause as evidence of the parties' intention in respect of the applicable law. ${ }^{81}$

\section{A HARD BREXIT}

\section{Introduction}

There are numerous circumstances (foreseen and unforeseen) that may jeopardise the continued application of EU legislation in the UK. First, the transposition of EU law resulting from the Great Repeal Bill may not be exactly what the leave campaigners intended when they sought to "take control" of British laws. ${ }^{82}$ Secondly, in the current political climate, those

International Contracts 117 and Plender and Wilderspin The European Private International Law of Obligations 151.

76 Groupe européen de droit international privé (GEDIP) (see http://www.gedip-egpil.eu).

77 GEDIP "Third Consolidated Version of a Proposal to Amend Articles 1, 3, 4, 5, 6, 7, 9, 10bis, 12 and 13 of the Rome Convention of 19 June 1980 on the Law Applicable to Contractual Obligations, and Article 15 of the Regulation 44/2001/EC (Brussels I)" (Vienna 2003) per http://www.gedip-egpil.eu/documents/gedip-documents-13vce.html: "In particular, the choice of a court or the courts of a given State shall not in itself be equivalent to a choice of law of that State."

78 The Rome Convention does not make any mention of choice of forum clauses.

79 Marshall 2012 Melbourne Journal of International Law 519; and Neels 2016 UNIDROIT 362-363. Briggs Private International Law in English Courts 541-542 suggests that a choice of arbitral tribunal is completely irrelevant in respect of choice of law.

80 See, Mandery Party Autonomy in Contractual and Non-Contractual Obligations 53: Recital 12 falls short of ensuring certainty as to the law. There remains scope for divergent interpretation, especially considering the different approaches taken by Member States. For a discussion in this regard, see Neels 2016 UNIDROIT 362-363 and Plender and Wilderspin The European Private International Law of Obligations 154. Recital 12 is limited to exclusive choice of forum clauses in respect of court or tribunals "of a Member State".

81 Briggs Private International Law in English Courts 542; Marshall 2012 Melbourne Journal of International Law 520; and Plender and Wilderspin The European Private International Law of Obligations 154.

82 MacMillan 201627 King's LJ 424. 
politically responsible for handling the withdrawal may not be open to the idea of maintaining any traces of the UK's prior membership. ${ }^{83}$ Thirdly, an agreement on the continued application of the current legal framework requires consent from the EU. ${ }^{84}$ Such consent may be withheld, as setting an example to other member states considering a similar Brexit-like path. ${ }^{85}$ Furthermore, the EU's consent will almost certainly depend on the UK accepting the jurisdiction of the Court of Justice of the European Union (CJEU). ${ }^{86}$ However, one of the central objectives of Brexit and the UK government was "to bring an end to the jurisdiction of the CJEU in the UK". ${ }^{87}$ Notwithstanding the fact that the UK may decide to apply EU law unilaterally via the Great Repeal Bill if such consent is not obtained, if the UK courts do not give "due account" to future CJEU decisions, or historic CJEU case law is no longer binding post Brexit, this would jeopardise the very purpose of the EU instruments. ${ }^{88}$ The continued unilateral application of EU Regulations would result in divergent interpretations from the member states, on the one hand, and the UK on the other, which will only create the illusion of uniformity as opposed to ensuring its long-term uniform application. ${ }^{89}$

83 Dickinson 201612 Journal of Private International Law 210. See, for eg, Schillig 201627 King's LJ 431: "[M]any signs point towards a 'hard Brexit' as the preferred option for many politicians involved in the negotiating process". See, also, Rühl www.law.ox.ac.uk/business law-blog/blog/2017/04/brexit-negotiations-series-effect-brexit-resolution-international: who believes that the Rome Convention will not be revived after Brexit.

84 Rühl www.law.ox.ac.uk/business-law-blog/blog/2017/04/brexit-negotiations-series-effectbrexit-resolution-international.

85 lbid.

86 Rühl www.law.ox.ac.uk/business-law-blog/blog/2017/04/brexit-negotiations-series-effectbrexit-resolution-international. The court encompasses three distinct courts (Court of Justice, General Court, and Civil Service Tribunal) that exercise the judicial functions of the EU, which aims to achieve greater political and economic integration among EU Member States. Originally established in 1952 as the Court of Justice of the European Coal and Steel Communities to ensure observance of the law "in the interpretation and application" of the EU treaties, the CJEU currently holds jurisdiction to review the legality of institutional actions by the European Union, ensure that Member States comply with their obligations under EU law, and interpret European Union law at the request of the national courts and tribunals (see http://www.ijrcenter.org/regional-communities/court-of-justice-of-the-european -union/ (accessed 2017-07-06)). The CJEU interprets EU law to ensure it is applied in the same way in all EU countries, and settles legal disputes between national governments and EU institutions. Individuals, companies and organisations can also access the court to take action against an EU institution, if they feel it has infringed their rights (see https://europa.eu/european-union/about-eu/institutions-bodies/court-justice en (accessed 2017-07-06)). For further information, see European Sources Online Information Guide Court of Justice of the European Union (see http://aei.pitt.edu/74891/1/Court_of_Justice.pdf (06/07/2017)).

87 Rühl www.law.ox.ac.uk/business-law-blog/blog/2017/04/brexit-negotiations-series-effectbrexit-resolution-international.

88 Rühl www.law.ox.ac.uk/business-law-blog/blog/2017/04/brexit-negotiations-series-effectbrexit-resolution-international; Requejo http://lawofnationsblog.com/2017/03/27/brexitprivate-international-law/.

89 Ibid. 


\section{Party autonomy and tacit choice of law}

In a hard-Brexit scenario, the UK would have to resort to the traditional common-law position to determine the applicable law. ${ }^{90}$ In English law, the legal system by which the parties intended the contract be governed may be termed the proper law of the contract. ${ }^{91}$ In Amin Rasheed Shipping Corporation v Kuwait Insurance Co, ${ }^{92}$ Lord Diplock described the proper law of a contract as "the substantive law of the country which the parties have chosen as that by which their mutually legally enforceable rights are to be ascertained". ${ }^{33}$ Frequently cited as the first English authority on party autonomy, the obiter dictum of Lord Mansfield in Robinson $v$ Bland ${ }^{94}$ provided that "[t]he law of the place [of contracting] can never be the rule, where the transaction is entered into with the express view to the law of another country as the rule by which it is to be governed". ${ }^{55}$ The principle of party autonomy has become a significant feature of English private international law. ${ }^{96}$ However, a common question is whether the freedom of the parties to select the proper law in completely unfettered. ${ }^{97}$ The liberal interpretation of party autonomy starts with the decision of the Privy Council in Vita Food Products $v$ Unus Shipping Co Ltd, ${ }^{98}$ where the court held:

"It is true that in questions relating to the conflict of laws rules cannot generally be stated in absolute terms but rather as prima facie presumptions. But where the English rule, that intention is the test, applies, and where there is an express statement by the parties of their intention to select the law of the contract, it is difficult to see what qualifications are possible, provided the intention expressed is bona fide and legal, and provided there is no reason for avoiding the choice on the ground of public policy."

90 Rühl www.law.ox.ac.uk/business-law-blog/blog/2017/04/brexit-negotiations-series-effectbrexit-resolution-international.

91 Morris (gen ed) Dicey and Morris on The Conflict of Laws (1980) 747-748. North Cheshire and North Private International Law (1979) 195; Graveson Conflicts of Law (1974) 405-406. See Mount Albert Borough Council v Australasian Temperance and General Life Assurance Society 1938 AC 224 240: "The proper law of the contract means that law which the English court is to apply in determining the obligations under the contract." See, also, Vita Food Products v Unus Shipping Co. Ltd 193963 Lloyd's Rep 21 27: "It is now well settled that by English law the proper law of the contract is the law which the parties intended to apply." 1984 AC 50.

61-62.

17602 Burr 1077

95 As referred to in Morris (gen ed) Dicey and Morris on The Conflict of Laws 751. See, also, Nygh Autonomy in International Contracts 5.

96 Tovey and Spurin "Private International Law Lecture Eleven: The Common Law Rules Governing the Choice of Law in Contract" (11 October 2007) www.nadr.co.uk/articles/articles.php?categories $=61$ (accessed 2017-07-11) 2; North Cheshire and North Private International Law 199; Morris (gen ed) Dicey and Morris on The Conflict of Laws 753-754. See, for eg, Rex $v$ International Trustee for the Protection of Bondholders Aktiengesellschaft 1937 AC 500 529; Vita Food Products v Unus Shipping Co Ltd supra 27; Whitworth Street Estates (Manchester) Ltd $v$ James Miller and Partners Ltd 1970 AC 583603.

97 North Cheshire and North Private International Law 199; Morris (gen ed) Dicey and Morris on The Conflict of Laws 753-754.

98 Supra.

9927. 
Subject to certain limitations, ${ }^{100}$ contracting parties have a wide discretion to agree expressly upon a governing law. ${ }^{101}$ However, when the parties fail to make an express choice of law, "the only certain guide is to be found in applying sound ideas of business, convenience, and sense to the language of the contract itself, with a view to discovering from it the true intentions of the parties" ${ }^{102}$ Therefore, in the absence of an express choice, it is possible for the court to determine whether there is an implied or inferred choice of law. ${ }^{103}$

\section{Level of strictness for a tacit choice of law}

The court in Jacobs, Marcus and Co $v$ Crédit Lyonnais ${ }^{104}$ provided that, in the absence of an express selection, the "true intention" of the parties must be discovered. ${ }^{105}$ In order to discover the true or real intention of the parties, rather than a purely hypothetical one, requires a criterion for identifying the choice of law to be articulated clearly and stringently. ${ }^{106}$ The traditional common-law test, as declared by Lord Diplock in Amin Rasheed Shipping Co v Kuwait Insurance $\mathrm{Co}^{107}$ required an examination:

"[l]n order to see whether the parties have, by its express terms or by necessary implication from the language used, evinced a common intention as to the system of law by reference to which their mutual rights and obligations under it are to be ascertained."

100 See, generally, Morris (gen ed) Dicey and Morris on The Conflict of Laws 754-756 on mandatory rules and public policy considerations. See, also, North Cheshire and North Private International Law 199-202.

101 Morris (gen ed) Dicey and Morris on The Conflict of Laws 753. See, for eg, an obiter dictum in Whitworth Street Estates (Manchester) Ltd v James Miller and Partners Ltd supra 603: "Parties are entitled to agree what is to be the proper law of their contract ... There have been suggestions that parties ought not to be so entitled, but in my view there is no doubt that they are entitled to make such an agreement, and I see no good reason why, subject it may be to some limitation, they should not be so entitled." See, also, Rex $v$ International Trustee for the Protection of Bondholders Aktiengesellschaft supra 529; and Lord Diplock's dictum in Amin Rasheed Shipping Corporation v Kuwait insurance Co supra 61: "English conflict rules accord to the parties to a contract a wide liberty to choose the law by which their contract is to be governed."

102 Jacobs, Marcus and Co v Crédit Lyonnais 1884 QBD 589601 (CA). See, also, Morris (gen ed) Dicey and Morris on The Conflict of Laws 761.

103 Morris (gen ed) Dicey and Morris on The Conflict of Laws 761; North Cheshire and North Private International Law 203. See, for eg, Compagnie d'Armement Maritime SA v Compagnie Tunisienne de Navigation SA 1971 AC 572 595; Amin Rasheed Corporation v 104 Supra. insurance Co 61; Bonython v Commonwealth of Australia 1951 AC 201221.

105601.

106 See par 3 3. See, also, Graveson Conflicts of Law 412: "There is, however, often a 'sense of unreality' in the process of trying to find an intention which may never have existed in respect of the law governing a breach of contract that was never contemplated when the contract was made."

1071984 AC 50.

108 61. See, also, Marshall 2012 Melbourne Journal of International Law 516; and Nygh Autonomy in International Contracts 111. 
Marshall opines that the phrase "by necessary implication" suggests a less stringent test than the "clearly demonstrated" criterion of the Rome I Regulation. ${ }^{109}$ One may argue that this criterion does not go far enough in the pursuance of legal determinability. ${ }^{110}$

\section{Indicators of a tacit choice}

The court in Vita Food Products stated that if a choice of law is not expressed, that it must "be presumed from the terms of the contract and the relevant surrounding circumstances". ${ }^{111}$ To determine whether the relevant intention of the parties is present, the court can infer a choice of law from the terms of the contract, and from the general circumstances of the case. ${ }^{112}$

There are a number of factors from which a court may infer a choice of law. For instance, the use of a standard form which is known to be drafted with reference to a particular system of law, ${ }^{113}$ an express choice of law in related transactions, ${ }^{114}$ and the inclusion of language or terminology appropriate to a particular system of law. ${ }^{115}$ Other factors, from which a choice may be inferred, include the residence of the parties, the nationality of the parties, and the currency in which payment is made. ${ }^{116}$ A choice of law in favorem negotii may also be added in this regard. ${ }^{117}$ The existence of any

109 See par 3 3. See, also, Marshall 2012 Melbourne Journal of International Law 516.

110 See par 3 3. See, also, Nygh Autonomy in International Contracts 111: "In that case, a single factor, such as a choice of jurisdiction clause, may suffice."

111 Supra 27.

112 Graveson Conflicts of Law 412; and Morris (gen ed) Dicey and Morris on The Conflict of Laws 761. See Compagnie d'Armement Maritime SA v Compagnie Tunisienne de Navigation SA supra: "[I]t requires the consideration together of the terms and nature of the contract, and the general circumstances of the case". See, also, Rex $v$ International Trustee for the Protection of Bondholders Aktiengesellschaft supra 529.

113 See, for eg, Whitworth Street Estates (Manchester) Ltd v James Miller and Partners Ltd supra 592-595. See, also, Morris (gen ed) Dicey and Morris on The Conflict of Laws 763: "The fact that the form or wording of a contract has been approved or prescribed by the authorities of a given country or by the head office of a commercial undertaking with branches in a number of countries may be a pointer towards the proper law." However, see, Nygh Autonomy in International Contracts 115: there should not be too much made of the use of a standard form; the use of a standard form by itself cannot be a useful indicator of a real intention. See, also, Compagnie d'Armement SA v Compagnie Tunisienne de Navigation SA 1971 AC 572.

114 North Cheshire and North Private International Law 206. See, also, Morris (gen ed) Dicey and Morris on The Conflict of Laws 764: "[T] he legal or commercial connection between on contract and another may enable a court to say that the parties must be held implicitly to have submitted both contracts to the same law". See, for eg, Re United Railways of the Havana and Regla Warehouses Ltd 19602 All ER 332.

115 Rex $v$ International Trustee for the Protection of Bondholders Aktiengesellschaft supra 553-554; Whitworth Street Estates (Manchester) Ltd v James Miller and Partners Ltd supra 603-608; Compagnie d'Armement SA v Compagnie Tunisienne de Navigation SA supra 594. See, also, Morris (gen ed) Dicey and Morris on The Conflict of Laws 762-763; North Cheshire and North Private International Law 205: the use of a particular language is a relatively unimportant factor; and Graveson Conflicts of Law 427-428.

116 North Cheshire and North Private International Law 205-206; and Morris (gen ed) Dicey and Morris on The Conflict of Laws 764.

117 Morris (gen ed) Dicey and Morris on The Conflict of Laws 765: "[T]he court may incline towards applying a system of law under which the contract would be valid because, so it is 
of the abovementioned factors are mere indicators that point to a common intention of the parties, the inference that a court draws from their existence should depend on all the circumstances of the case. ${ }^{118}$

\section{Choice of forum and tacit choice of law}

At common law, the courts have attached considerable weight to an agreement in the contract stipulating that any dispute shall be submitted to the courts of a particular country as signalling a choice of law. ${ }^{119}$ Similarly, a localised arbitration clause also permits the inference that the law of that country was intended as the proper law of the contract. ${ }^{120}$ In Hamlyn $v$ Talisker Distillery, ${ }^{121}$ for instance, Lord Herschell LC stated:

"[T]he language of the arbitration clause indicates very clearly that the parties intended that the rights under that clause should be determined according to the law of England. The parties agree that any dispute arising out of their contract shall be 'settled by arbitration by two members of the London Corn Exchange, or their umpire, in the usual way,' it seems to me that they have indicated as clearly as it is possible their intention that that particular stipulation, which is a part of a contract between them, shall be interpreted according to and governed by the law, not of Scotland, but of England, and I am aware of nothing which stands in the way of the intention of the parties thus indicated by the contract they entered into, being carried into effect."

This presumption is based on the principle qui eligit judicem eligit ius, which has generally resulted in English courts treating an express choice of a court or arbitral tribunal as an implied choice of the proper law. ${ }^{123}$ The principle was pushed to its extreme in Tzortzis and Sykias $v$ Monarch Line $A / B{ }^{124}$ where Salmon LJ stated that an arbitration clause raises "an irresistible inference which overrides all other factors". ${ }^{125}$ However, this was

said, the parties cannot be assumed to have intended to contract under a law by which their agreement would be invalid. The importance of this argument should not be exaggerated, because the court may find that the intention of the parties was in fact directed towards a law under which, in the event, their contract - or part of it - turned out to be void. It is therefore dangerous to put too much reliance on the argument". See, also, North Cheshire and North Private International Law 206.

118 Morris (gen ed) Dicey and Morris on The Conflict of Laws 764.

119 North Cheshire and North Private International Law 203; Morris (gen ed) Dicey and Morris on The Conflict of Laws 761; and Graveson Conflicts of Law 417.

120 Ibid.

1211894 AC 202

122 208. See, also, Spurrier v La Cloche 1902 AC 446 450; Kwik Hoo Tong Handel Maatschappij v James Finlay and Co Ltd 1927 AC 604 608-610.

123 See, North Cheshire and North Private International Law 203-204 and Graveson Conflicts of Law 417: English courts have generally treated the choice of arbitrators as an automatic choice of the proper law. A choice of jurisdiction clause contains a powerful implication that the law of that country should be applied. See, also, Morris (gen ed) Dicey and Morris on The Conflict of Laws 761: "If they (the parties) agree that the courts of a given country shall have jurisdiction in any matters arising out of a contract, they can - in the absence of evidence to the contrary - be assumed to have intended those courts to apply their own law and thus to have selected that law as the proper law of the contract."

12419681 Lloyd's Rep 337.

125 341. See, also, North Cheshire and North Private International Law 204; Morris (gen ed) Dicey and Morris on The Conflict of Laws 762; and Graveson Conflicts of Law 418-420. 
refuted in Compagnie d'Armement Maritime SA v Compagnie Tunisienne de Navigation $S A,{ }^{126}$ where the court held that a contract containing an arbitration clause was not necessarily a conclusive factor pointing toward a tacit choice of law, although it was a "weighty" indication that the parties intended the law of that place to govern the contract. ${ }^{127}$ Although the court did not go as far as the Tzortzis case, it still placed considerable emphasis on a choice of arbitration clause. ${ }^{128}$

\section{$5 \quad$ CONCLUSION}

It would be naive to think that the uncertainty facing the UK in respect of private international law would be on top of the agenda during the Brexit negotiation process. ${ }^{129}$ Nevertheless, it remains an important consideration going forward - hopefully one that will be ironed out before the eventual withdrawal. ${ }^{130}$ In respect of the applicable law, the consequences of Brexit may be fairly contained than other areas in private international law. ${ }^{131}$ In a soft-Brexit scenario, the UK may seek to retain the benefits of existing EU Regulations, including the Rome I Regulation. ${ }^{132}$ Alternatively, it may be possible for the UK to retain the (largely identical) 1980 Rome Convention, as enacted by the Contracts (Applicable Law) Act 1990. In a hard-Brexit scenario, the UK would have to resort to their traditional common-law position in this regard. ${ }^{13}$

126 Supra.

127 596. See, also, Morris (gen ed) Dicey and Morris on The Conflict of Laws 762; North Cheshire and North Private International Law 204-205; and Graveson Conflicts of Law 420-424.

128 For instance, Lord Reid remarked at 584: "[T] he fact that the parties have agreed that arbitration shall take place in England is an important factor and in many cases it may be the decisive factor. But it would in my view be highly anomalous if our law required the mere fact that arbitration is to take place in England to be decisive as to the proper law of the contract". Lord Wilberforce observed at 600: "Always it will be a strong indication; often, especially where there are parties of different nationality or a variety of transactions which may arise under the contract, it will be the only clear indication. But in some cases it must give way where other indications are clear." Finally, Lord Diplock stated at 604: "The fact that they have expressly chosen to submit their disputes under the contract to a particular arbitral forum of itself gives rise to a strong inference that they intended that their mutual rights and obligations under the contract should be determined by reference to the domestic law of the country in which the arbitration takes place, since this is the law with which arbitrators sitting there may be supposed to be most familiar. But this is an inference only. It may be destroyed by inferences to the contrary." See, also, Bangladesh Chemical Industries Corp v Henry Stephens Co Ltd 19812 Lloyd's Rep 389 CA 392: the court acknowledged that an arbitration clause choosing London as the seat of arbitration, no longer automatically led to the inference that English law was the law chosen by the parties. The court did state, however, that an arbitration clause in the contract "is of the very first importance".

129 Dickinson 201612 Journal of Private International Law 209.

130 lbid.

131 MacMillan 201627 King's LJ 430.

132 See par 3.

133 See par 42 
The post-Brexit consequences for the determination of a tacit choice of law will be even less marked. ${ }^{134}$ First, the level of strictness of the criterion under the Rome I Regulation requires the choice to be "clearly demonstrated", ${ }^{135}$ while the formulation under the Rome Convention requires the tacit choice of law be "demonstrated with reasonable certainty" ${ }^{136}$ Lord Diplock describes the traditional common law test in Amin Rasheed Shipping Co v Kuwait Insurance $\mathrm{Co}^{137}$ using the phrase "by necessary implication". ${ }^{13}$

The position both under the Rome model and under the common law is that a court must examine the provisions of the contract and the general circumstances of the case in searching for indicators of a choice of law. ${ }^{139}$ The Giuliano and Lagarde Report list various examples from which a tacit choice of law may be inferred. ${ }^{140}$ As is the position under the report, the English courts have traditionally taken the use of a standard form and an express choice of law in a related transaction as evidence of a tacit choice of the relevant country's law. ${ }^{14}$

Although the Rome Convention is silent on the role of choice of forum clauses, the Rome I Regulation attempts to address the issue. ${ }^{142}$ However, recital 12 in its present form is ambiguous and allows for different interpretations. ${ }^{143}$ The intention behind recital 12 should be made clear by stating whether a choice of forum is not sufficient to indicate a choice of law but may be a factor to be taken into account, or whether a choice of forum clause may on its own indicate a choice of law. At common law, the courts have attached considerable weight to the fact that the parties have agreed to submit their disputes to the courts of a particular country, or arbitration in a particular country.

The new relationship between the UK and the EU is completely uncertain, and many doubts concerning the legal regime of cross-border civil and commercial matters are at the root of this uncertainty. ${ }^{145}$ Whatever outcome Brexit holds, one incontrovertible fact is that the UK's representatives need to appreciate the nature of the impending private international law problems and formulate effective strategies to minimise this uncertainty. ${ }^{146}$

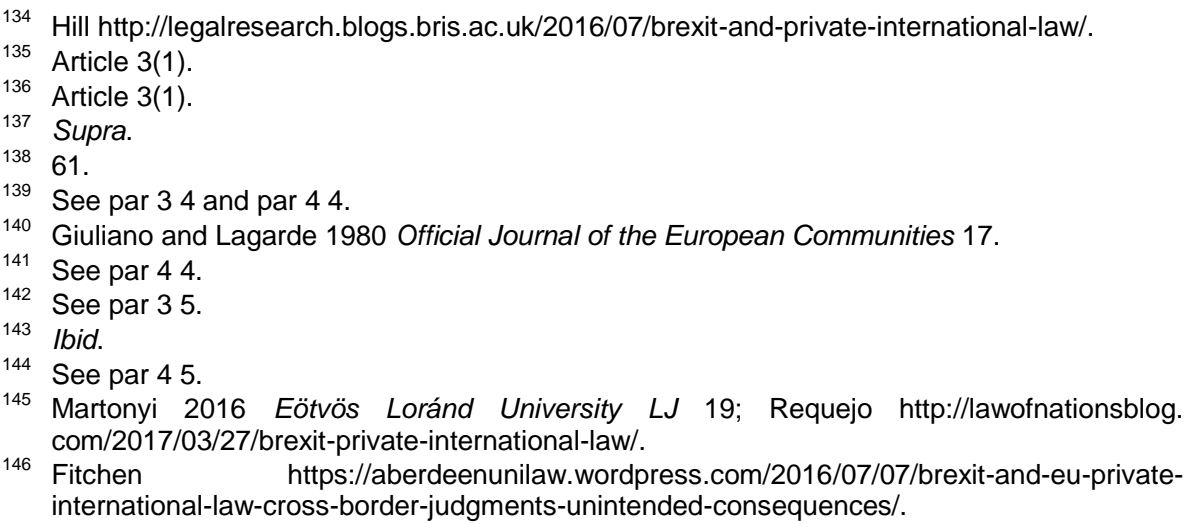

